Special Issue "Lake Restoriation"

Guest Edited by Dr. Renata Augustyniak and Dr. Renata Dondajewska-Pielka

Limnol. Rev. (2021) 21, 2: 105-118

DOI 10.2478/limre-2021-0010

\title{
Lakes restoration approaches
}

\author{
Mohammed Z. Alhamarna, Renata Tandyrak
}

\author{
Department of Water Protection Engineering and Environmental Microbiology \\ University of Warmia and Mazury in Olsztyn, ul. Prawocheńskiego 1, 10-720 Olsztyn, Polan \\ mohammed.alhamarna@uwm.edu.pl, renatat@uwm.edu.pl (corresponding author)
}

\begin{abstract}
Preventive and curative intervention become an imperative to encounter the recent dilemmas of lakes and its ecosystem, eutrophication, external contaminants load and the internal load and hydrological cycle disruption, lakes drought or flood as a result of the global warning are some of these dilemmas which mainly caused anthropogenic activities. At present, mechanical and chemical treatment approaches are the most popular applied techniques for lakes remediation with an escalating pace of biological methods are implemented as biomanipulation; which consider an efficient eco-technique. As experience has proven, desirable reclamation result is achieved by implementing combination of the restoration methods.
\end{abstract}

Key words: reclamation of water reservoirs, water protection, management of protection, pollution

\section{Introduction}

The ongoing process of degradation of water reservoirs and the increasing costs of water treatment (Lewtas et al. 2015, Glibert et al. 2005) force us to look for effective methods to reduce their trophy, reverse or at least inhibit this process. The beginning of this type of activity dates back to the forties of the last century (Thomas 1944), however, attempts to widely implement these methods did not take place until the mid - 1950s, and their widespread use 10 years later (Lossow 1995). Over the years, constant development and improvement of these methods has been observed (Cooke et al.2005, Born 1979, Dunst et al. 1974) and various techniques are combined to achieve the best results (Grochowska et al. 2020, Grochowska et al. 2013, Łopata and Wiśniewski 2013). The reason for these activities is usually one and the same the water in lakes (usually in urban lakes) is characterized by poor condition. For the ordinary city dweller this means low transparency of water, massive algae blooms, especially cyanobacteria, and an unpleasant smell. This reduces aesthetic qualities of the lake and excludes it from recreational use
(Parszuto et al. 2018). These very basic symptoms of advanced eutrophication are forcing the authorities to take a remedial action. First of all, basing on various factors, as: lake morphometry, seasonal nutrient loading and concentrations, stratification, sediment and water quality, water chlorophyll a, Secchi disk visibility, phosphorus and nitrogen concentrations, it is necessary to determine the reason for such a state of (Hickey and Gibbs 2009). All pollution sources should be inventoried and pollution loads from these sources should be calculated. This will allow you to estimate the actual level of supply of organic and biogenic matter from the catchment (Łopata et al. 2020). You have to determine the lake's own capacity to absorb these pollutants (Gawrońska et al. 2007) and have to consider an intermediate catchment area. For many reservoirs an important source of pollution is an inflowing water. These very beginning actions allow to recognize and organize the hydrological and catchment pattern, which is the basis for lake protection (Carvahlo et al. 1995, Cullen and Forsberg 1988) and necessary for successful remediation (Mehner et al. 2002, Sas 1990). If the lake is not heavily polluted and the reduction of phosphorus pollution exceeds $90 \%$, its 
spontaneous deeutrophication may occur (Jeppsen et al. 2005, Cullen and Forsberg 1988), but in other cases the improvement of the lake is little or none. This applies especially to those reservoirs in which internal loading from bottom sediments has become an important source of nutrients (Smolders et al. 2006). Then a restoration activity is the only hope for the lake. Unlike protection methods, the lake renovation brings faster improvement of water quality than the tedious, long-term reduction of nutrient inflow from the catchment. However, it should be emphasized that reclamation is a very expensive procedure, so it must be well thought out and well planned. Due to the wide range of possibilities in this area it is particularly important to pay special attention to the need of treat each object individually (Bartoszek et al. 2015, Sřndergaard et al. 2007, Klapper 2003).

The review highlights the proven implemented techniques for lake restoration process, attempt to introduce a summarized review, that is capable to create a well-background for reader about lakes reclamation history, ongoing applied methods and the future trends. These paper exhibit technique itself without the spatial implementation occurrence.

\section{Approaches to lake protection and restoration}

Most lake pollution problems are caused by nutrients, contaminants, and sediments due to erosion or sinking and decomposition of dead species and plankton (Table 1).

These pollutants could an external which are carried into lake from diffusive/nonpoint sources as; a) using of agricultural fertilizers, herbicides and pesticides in lake catchment area, b) runoff and what it could carry to lake body, c) atmospheric fallout e.g. acid rain precipitation or a point source as in case of pumping sewage. (Dobson et al. 1974). While the internal loading usually refers to recycling of nutrients from sediments, primarily through redox reactions at the sediment-water interface and decomposition of settling organic matter (Smolders et al. 2006).

Generally, all activities related to lake restoration processes fall under two main categories; management and preventive out-side the lake, and a direct in-lake methods (Fig. 1).

\section{Management and protection methods}

\section{Adjustment of lake's catchment drains}

Management practices attempts to reduce nutrient or sediment export rates to the waterbody through an alterations of lake drainage basin (Singh 1982). The rate of nutrients export from the catchment is influenced by factors as; meteorological conditions, land-use, soil type, land slope and

Table 1 . The main lake stress factors, causes and ecosystem consequences (based on Klapper 2003, changed)

\begin{tabular}{|c|c|c|}
\hline Lake stress factors & Main reasons & Ecosystem consequences \\
\hline Water level decline & $\begin{array}{l}\text { Overuse of the drawn water from the lake } \\
\text { itself. } \\
\text { Decrease in feeding water amount. } \\
\text { Increase outflow from the lake. }\end{array}$ & $\begin{array}{l}\text { Increase the salt concentration } \\
\text { Temporary advance of eutrophication }\end{array}$ \\
\hline Eutrophication & $\begin{array}{c}\text { Nutrient load from both point or diffuse } \\
\text { sources }\end{array}$ & $\begin{array}{c}\text { Unwanted high plant growth, algae blooms } \\
\text { and fish kills }\end{array}$ \\
\hline $\begin{array}{l}\text { Saprobization } \\
\text { and microbial infection }\end{array}$ & $\begin{array}{c}\text { Organic matterload as a BOD from: } \\
\text { anthropogenic sources } \\
\text { natural sources } \\
\text { autochthonous biomass }\end{array}$ & Oxygen depletion and fish kills \\
\hline Acidification & $\begin{array}{l}\text { Acid rain with } \mathrm{SO}_{2} \text { and } \mathrm{NO}_{x} \\
\text { geogenic sulfur acidification from pyrite ox- } \\
\text { idation }\end{array}$ & $\begin{array}{l}\text { Low pH, metal load, absence of hydrogen } \\
\text { carbonate, low species diversity }\end{array}$ \\
\hline Salinization & $\begin{array}{l}\text { Transpiration losses by irrigation and the } \\
\text { surface connections to salt layers }\end{array}$ & $\begin{array}{l}\text { Decressing of lake's size and throughflow, } \\
\text { in addition to meromixis occurrence. }\end{array}$ \\
\hline Contamination & $\begin{array}{l}\text { Hazardous substances: industrial wastes; ni- } \\
\text { trate or pesticides from agriculture }\end{array}$ & $\begin{array}{c}\mathrm{O}_{2} \text {-depletion and obstructing lake's self-pu- } \\
\text { rification process }\end{array}$ \\
\hline
\end{tabular}




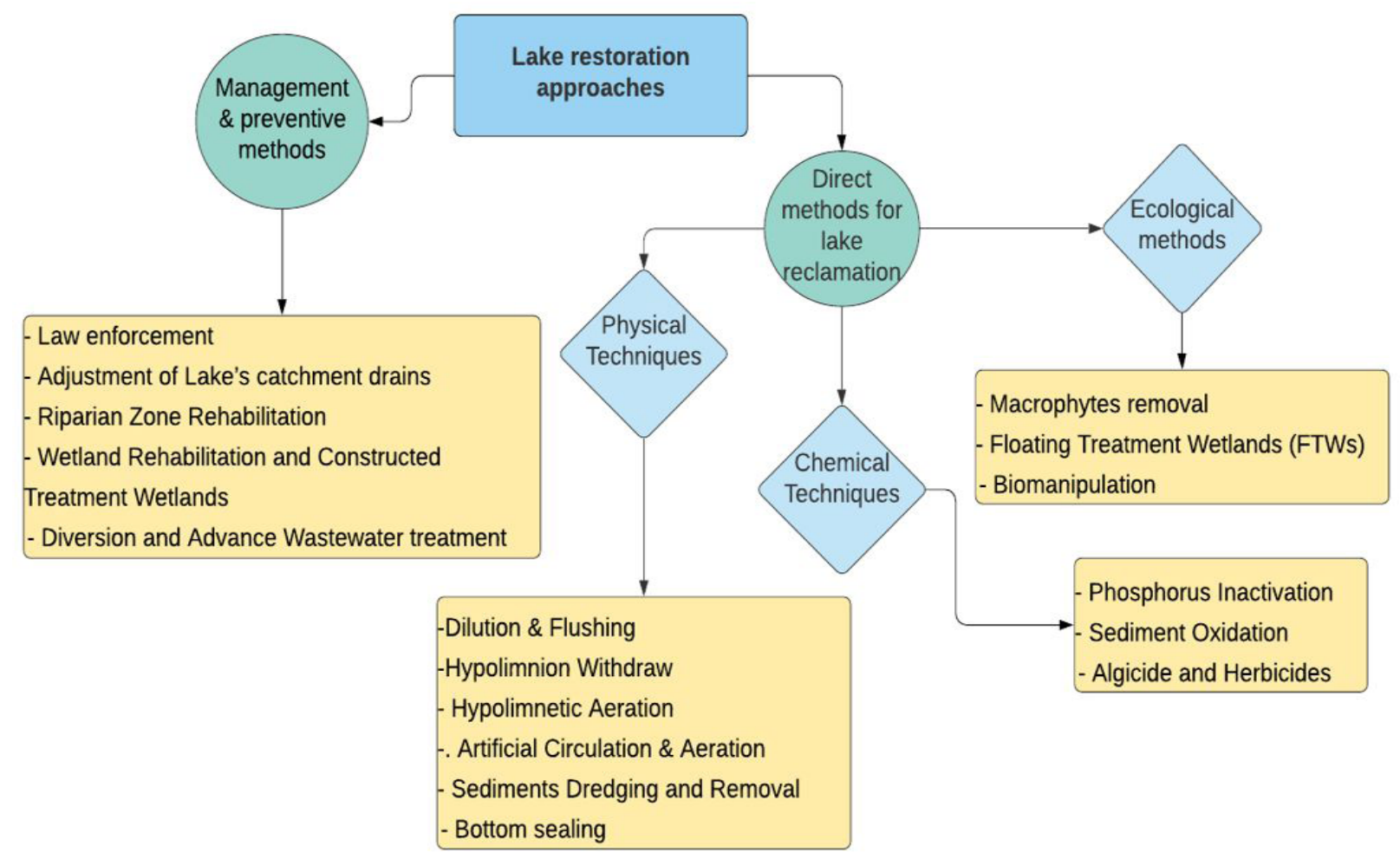

Fig. 1. Activities related to lake restoration processes

geology, rainfall intensity, drainage density and catchment size, where the land-use factor is best predictor of nutrient export rates (Omernik 1977). The management practices comprise source controls in urban areas, fertilizer application rates for agriculture, erosion controls and mechanical techniques to intercept and trap sediments, such as buffer strips and artificial wetlands (Young et al. 1996). Numerous hydrological models have been developed to calculate and predicate amounts of water and nutrients flowing across a catchment from diffusive sources into the receiving waterbody and its impact, these models can be classified as physically based, conceptual and empirical data-driven models (Todini 2007, Shepherd et al. 1999). Some of the assistance software toolkits are; Modflow, the Hydrological Engineering Center-Hydrological Modeling System (HEC-HMS), Soil and Water Assessment Tool (SWAT), Catchment Management Support System (CMSS), Water and Contaminant Analysis and Simulation Tool (WaterCAST), and others more, selecting the appropriate model and software depend on the purpose of the analysis and the available data (Bormann et al. 2005, Payraudeau et al. 2001).

\section{Riparian zone rehabilitation}

The riparian zone in lake consider as a significant biome with big influence on the water cycle as well as in many independent nutrient cycles, and helps to reduce surface and sub-surface runoff volume, protects banks from erosion, lowers pollutant concentrations in downstream, supports the aquatic food webs by exporting the particulate and dissolved organic material and serves as an important wildlife corridor, allowing species to pass without interacting with humans (Riis 2020, Clerici et al. 2016, Wall et al. 2001). The riparian zone is characterized by a high species diversity that help to filter the water. It could be submerged, emergent, semi-terrestrial and terrestrial vegetation, with a high biomass, productivity and retention of materials (Dufour and Rodríguez-González 2019).

Establishing a vegetative buffer zone or just enhance and restore the exist riparian zone in the inflows would provide protection by intercepting nutrients and sediments, and assists in restoring lost biodiversity (Arsénio et al. 2019). There are five general ways that buffers can function to reduce the nonpoint source pollution from land: a) reduce surface runoff, b) filter surface runoff, c) filter 
groundwater, d) reduce bank erosion, and e) filter pollutants from stream water (Schmitt et al. 1999, Alberts et al. 1981).

\section{Wetland rehabilitation and constructed treatment wetlands}

As the natural wetlands retain water and store nutrients and other contaminants and restoration of wetlands can return function to the landscape, thereby protecting lakes and streams, as well as reducing the volume and frequency of floods (Cairns et al. 1992). Alternatively, construction of new wetlands to control and treat nutrient loading from the diffuse sources will be a helpful approach to improve the introduced water quality to the lake (Braskerud 2002).

Constructed building wetlands are generally built on uplands and outside floodplains or floodways to avoid damage to natural wetlands and waterbodies. They can be constructed by excavating, backfilling, grading, diking and installing water control structures to established hydraulic flow patterns, then the wetland flora are planted or allowed to establish naturally (USEPA 2000).

\section{Diversion and advance wastewater treatment}

An advance treatment of the inflowed sewage effluent quality to lake or even turn its course to another waterbody that has greater assimilative capacity will participate to improve lake's quality. This is a primary method for a point source of pollution and it has to be taken in consideration to estimate all other pollution/nutrients inputs (Dąbrowska et al. 2017, Hamm 1978). A collection system may be a necessary part of the diversion project and the recovery rate may be slowed by internal loading (Lewtas et al. 2015).

In the cases cited by Dunst (1974), an increase in transparency, decrease in phytoplankton biomass, chlorophyll and nutrients as phosphorus $(\mathrm{P})$ and nitrogen $(\mathrm{N})$, combined with an increase in species diversity and oxygen level at the bottom were observed.

\section{Direct methods of lake reclamation}

The lake renovation methods consist in reducing the amount of biogenic substances circulating in the lake. This can be achieved either by: moving them outside the lake ecosystem (sediments removal, hypolimnetic with- drawal), permanent immobilization in bottom sediments.

Accordig to Kajak (2002), bottom sediments, especially their surface $10-\mathrm{cm}$ layer, are practically an unlimited source of phosphorus for lake water and $90-95 \%$ of phosphorus in the lake's ecosystem is deposited there. The same thickness of sediment layer was confirmed by Augustyniak (2018), Hosomi and Sudo (1992) say, that a layer involved in the exchange processes between sediment and water is much thinner, about $3-\mathrm{cm}$. Although there is a lack of compliance at this topic, it seems that the most reasonable and expedient is the use of such reclamation methods that aim to remove excess of nutrients beyond the lake ecosystem.

\section{Sediments removal}

There are a lot of reasons for removing sediment from a lake, including deepening, limiting the internal nutrient recycling, reducing macrophyte nuisance by light-limiting, removing toxic sediments and decrease cyanobacterial inocula, that will improve the overall water quality (Lewtas et al. 2015).

Two major techniques are applied for lake sediment removal: excavation or dredging. The dragging mechanism could be mechanical or hydraulic dredges (Björk et al. 2010).

The mechanical dredge operates most efficiently in near-shore areas and its efficiency declines rapidly with the depth of the lake. It is because the consumed time per the operating cycle, which done by grab-bucket dredges and drainage sediments discharge into a vicinity area, barges or trucks to transport it to a disposal area. While the hydraulic dredge technique is done by a cutterhead hydraulic pipeline dredge, with an advantage of less sediment resuspension (Cooke et al. 2005).

Usually, only contemporary part of sediments, the richest in organic matter and containing most mobile forms of nutrients (especially phosphorus), and often contaminated with heavy metals, are removed. It should be noted that the extracted sediments must not remain on the shore of the lake, they must be properly managed. Leaving them on the shore could cause secondary pollution of the lake. These deposits generate leachate containing huge amounts of nitrogen and phosphorus, significantly exceeding the concentrations recorded in the 
water column (Łopata et al. 2020). Resuspension of sediments has a negative impact on the aquatic biota, the reduction of light for the primary producers and destruction of benthic fish-food organisms' effect on a lake's food web (Palermo et al. 2008).

The main limitation of this method is the high cost of extraction and disposal of sediments. Their storage is associated with the devastation of adjacent areas. Technical infrastructure is also needed: sludge clarification tanks, leachate purification equipment or hydrotransport equipment (Grochowska et al. 2020).

The well-known example of this renovation method is Lake Trummen in Sweden (Björk 2010). In Poland this method is not very widespread, Lake Mogileńskie is known (Dąbrowska 2008). The renovation of the Karczemne Lake is currently underway, what is detaily described by Grochowska et al. (2020). In fact, Karczemne Lake case is a part of innovative activity of an urban lake system renovation.

\section{Hypolimnion withdrawal}

Accumulation of nutrients and contaminants as iron $(\mathrm{F}(\mathrm{II}))$ and ammonia in hypolimnion layer and lake bottom is a result of the redox cycling of iron and phosphorus under anoxic conditions and decomposition of settled organic matter. This treatment is applicable to stratified lakes and small reservoirs where anaerobic hypolimnion restrict habitat for fish and promote the release of $P$, toxic metal ions, and hydrogen sulphide from sediments. Hypolimnetic withdrawal technique is based on removing hypolimnetic water to the outflow, usually to the river. The treatment is applied by installing a pipe along the bottom of the lake, inlet over the deepest point. The outlet pipe is usually situated below lake level and acts as a siphon (Nürnberg 2019). This is usually accomplished by damming the surface outlet and displacing it by the drawn water from the hypolimnion (Klapper 2003). Consequently, decrease the hypolimnion retention time and chance for anaerobic conditions to develop and reducing nutrients availability for epilimnion layer (Lewtas et al. 2015).

Hypolimnetic withdrawal is a proven treatment technology to accelerate recovery in stratified lakes with high internal loading. The capital and operational cost of treatment is relatively low with a long-term effectiveness. Its efficiency depends on two main factors, that lake's water level must remain relatively constant.

In most of applied cases, hypolimnetic dissolved oxygen level increased which entails a decrease in the anoxic conditions and its duration (Cooke et al. 2005). Another potential advantage is that hypolimnetic water withdrawal may reduce the accessibility of cyanobacteria to Fe (II), which is now thought to be a precursor to the development of blue green algae blooms (Molot et al. 2014).

This method of renovation can be used in a stratified, flow lake with significant water change during the year (the whole hypolimnion volume should be removed at least once a year), the inflow and outflow from the lake should be situated opposite each other. There are some disadvantages in this method, where the outflow water contains high phosphorous, ammonia and hydrogen sulphide concentrations, in addition to a reduced metals and low oxygen content causing water-quality problems in the outflow, moreover the water may have a strong odour (Tandyrak et al. 2016).

This method of renovation was carried out on plenty of lakes in North America and Europe. The first in the world (in 1956 year) and the best documented method is implemented in Kortowskie Lake in Olsztyn (Poland) (Wiśniewski 2007, Mientki 1986). The pipeline has been working for more than sixty years.

\section{Dilution and flushing}

Nutrients concentration and loading are critical factors for algal biomass, adding more lownutrient water will increasing the water exchange rate with flushing, that's reduce lake's nutrient content (dilution) and increase nutrient and plankton losses through the outflow (Welch 1981). Dilution also improve the vertical mixing and decreased concentration of algal excretory products that can influence the abundances and species of algae (Keating 1977). The amount of water needed to achieve a given reduction in nutrients concentration is a function of the concentration diference between the normal inflow and dilution-water source, also the flushing rate must be a large fraction of the algal growth rate (Lewtas et al. 2015). The effectiveness of this restoration technique increases with an increase in the difference between nutrient concentrations in the inflow and lake water and it is the greatest when dilution's water is low in nutri- 
ent concentration rather than lake's water (Cooke et al. 2005). Water for diluting or flushing is usually used from underground water intakes, another less eutrophied reservoir or surrounding watercourses, artificially redirected to the lake subjected to reclamation (Łopata et el. 2020).

The strategy is economical if a suitable water's supply exists and the operational costs are not high. Dilution is shown to reduce phosphorus, chlorophyll a, and biomass with an improves for Secchi disk visibility (Singh 1982). This method was used on several lakes in the world, but satisfactory results were obtained seldom (Lossow and Gawrońska 2000).

\section{Bottom sealing}

Sediments may be physically capped to prevent difusion of nutrients and contaminants to the overlying water column (passive capping). The bottom can be covered with plastic polyethylene sheets - $0.1 \mathrm{~mm}$ thick, with perforations for the outflow of gases released by sediments, or by passive capping - using fly ash (Lossow et al. 1998), iron-rich sand (Kim et al. 2007), gravel, or clay with thickness typically exceeds $5 \mathrm{~cm}$ (Cullen and Forsberg 1988, Cooke 1980, Born 1979), zeolite (Gibbs and Özkundakci 2011), Phoslock with a bentonic clay modified with lanthanum (Gibbs at al. 2011), calcite (Berg et al. 2004), biochar (Zhu et al. 2019) or activated carbon (Gu et al. 2017). Most of this are experiments in laboratory scale.

This approach suitable for small lakes and has a short-term effect on nutrient and contaminants emission from sediments because the adsorptive capacity of added materials will be suppressed and a new organic matter will settle and bury the capping materials or growing of macrophyte on its surface (Singh 1982).

Various obstacles facing this technique, as the needed for a large material, difficulties depositing a uniform layer, provide poor benthic habitat and creating anoxic conditions below the sheet may interrupt fish spawning e.g. the fly ash which positively harmful with adverse effects on fish and zooplankton. It also leads to high $\mathrm{pH}$, low dissolved oxygen, and high concentrations of heavy metals (Lossow et al. 1998, Theis et al. 1979). Also, the boating activities and wave action may drive out it, a result of these limitations, physical capping agents are rarely used (Hickey and Gibbs 2009).

\section{Hypolimnetic aeration}

In stratified lakes, depletion of dissolved oxygen in hypolimnetic water result from respiration process of organic matter in lake and in sediments, it creates anoxic condition, which accelerate the internal nutrients load and metals solubility with a changes in biota and fish distribution (Siwek et al. 2018, Schönach et al. 2017, Cooke et al. 2005). Lake Bret in Switzerland, was the first in the world where hypolimnetic aeration technique was used. It was designed to counteract hypolimnetic anoxia and its associated effects on lake quality (Mercier and Perret 1949).

Aeration usually done by special aerators that the inject a pure oxygen or fine air-bubbles to the hypolimnion layer, without causing a destratification (Singleton and Little 2006). There are various designs of hypolimnetic aerators, they mainly grouped into three categories; a) mechanical agitation, that remove or treat and return of the hypolimnetic water, b) injection of pure oxygen, and c) injection of air, either full or partial airlift design or through a down-flow injection design (Fast and Lorenzen 1976). There are modern constructions enable the simultaneous introduction of coagulant, which significantly improves the effectiveness of the method (Łopata et al. 2020). Aerator's efficiency depends on the DO transport adequacy between air bubbles and pumped water (Ashley et al. 1992). The most commonly used designs in current use are the airlift aerator, Speece Cone, and bubble plume diffuser (Singleton and Little 2006)

Hypolimnetic aeration is not an efficient option if lake is shallow with depth less than 12-15 $\mathrm{m}$ or the hypolimnetic volume is relatively small, and it is typically used in lakes where it is desirable to maintain cold-water habitat and where whole lake circulation is not desirable (Cooke and Carlson 1989). One of the principal reasons for maintaining stratification during aeration is to prevent the recirculation of sediment-released $P$ and maintain habitat for cold-water biota. (Lewtas et al. 2015). The hypolimnion layer aerating can switch it from anoxic to an oxic state while still maintaining a coldwater environment and potentially decrease internal loading of phosphorus ( $\mathrm{P})$, iron (Fe), manganese $(\mathrm{Mn})$, ammonium $\left(\left(\mathrm{NH}_{4}{ }^{+}\right)\right.$, hydrogen sulphide $\left(\mathrm{H}_{2} \mathrm{~S}\right)$, and methyl mercury $\left(\mathrm{CH}_{3} \mathrm{Hg}\right)$ (McQueen and Lean 1984).

Aeration primarily reduces the internal $P$ 
loading by deactivate Fe-P redox reactions at the sediment-water interface, benthic zone. Where Fe and $\mathrm{P}$ interaction undergo through short-term cycle of $\mathrm{P}$ in lake and do not storage permanently in lake sediments, so such a long-term reduction can be achieved by decreasing nutrients external-load but also, phosphorus improvements do not always occur with aeration (Katsev 2006, McQueen and Lean 1986).

Hypolimnetic aeration may also increase diffusion of nutrients into the epilimnion even without causing destratification (Ashley 2011). Although with existing of stratification, the gradient density may not be sufficient to resist thermocline erosion. If the water body de-stratify, this may result a low content of dissolved oxygen throughout the water column and the introducing of toxic chemicals (e.g. $\mathrm{H}_{2} \mathrm{~S}$ ) into the epilimnion (Cooke and Carlson 1989, McQueen and Story 1986).

An innovative solution in lakes with a positive water balance could be a redirection of oxygenated surface inflows by pipeline to the deepest part of the reservoir. This type of installation works on Lake Łajs, Olsztyńskie Lakeland (Łopata and Wiśniewski 2013).

\section{Artificial circulation and aeration}

This restoration technique has been employed since the early 1950s, for West Lost Lake, a small Michigan trout lake (USA) (Hooper et al. 1953), and was initially used to prevent winter fish kills in shallow and ice-covered lakes (Halsey 1968).

The principal concept of circulation is to raise the dissolved oxygen content by oxygenation the whole water's column, which lead to oxidize the chemical substances, this is achieved by pumps, jets and diffused air (Ashley and Nordin 1999).

Complete circulation reduces the internal loading of phosphorus and trace elements and also complexifying of iron and manganese and accelerate their precipitation. This type of aeration enlarging the suitable habitat for aerobic warm-water species and enhancing conditions for more desirable algal species (Pastorok et al. 1981, 1982). Complete circulation may also reduce algal biomass by increasing the mixed depth, reducing available light and subjecting mixed algal cells to rapid changes in hydrostatic pressure.

According to Pastorok et al. (1982), artificial circulation efficiency determined by four indicators, as follow: dissolved oxygen content, ammonium, epilimnion's $\mathrm{pH}$ and the trace metals, iron and manganese. In most of the studied cases, the trace metal decreased and the dissolved oxygen content increase.

In case of destratification, additional concentration of dissolved oxygen in what was the hypolimnion is notice, but on the contrary, dissolved oxygen content in previous epilimnion layer initially decreased, until the equilibrium status achieved. Anyhow, the overall lake temperatures increase, that may adverse the cold-water biota and fish (Ashley 1987).

\section{Phosphorus inactivation}

Phosphorus is a limiting nutrient that can affect the trophic statues of the lake and reducing in its amount or solubility can highly enhance the water quality through the lake. Sediments are the mainly source of P-internal loading, where it works as a sorption sites, by binding it with the exist metal ions, as; iron, aluminium and calcium, but temporary $\mathrm{P}$ release can occur from reductant - soluble elements and mineralization of $P$ containing organic compounds, intrusion an external P-loading accelerate rapidly lake's phosphorous content (Huser and Pilgrim 2014, Hupfer et al. 1995, Nürnberg 1988).

Concept of phosphorus inactivation technique based on decreasing phosphorous mobility from the sediments and limit its cycle through the lake by increase sediment binding capacity of phosphorous and other contaminants, via an addition of P-sorbing Products (PSPs) as; alum, calcium (Ca), zeolite, PhoslockTM, and iron (Fe). This technique is called an active sediment capping (Lewtas et al. 2015, Huser and Pilgrim 2014).

Phosphorus inactivation is a proven successful treatment, with some precautions for each of the absorbents based on the lake characterizes and its use, usually implementation this method associates with reducing the planktonic microcrustacean species diversity and the rooted plant may increase (Lewtas et al. 2015, Sonnichsen 1978). Lake remediation with aluminium salts requires special care in calcium-poor lakes that are susceptible to acidification. The safe reaction is $6.0-8.5 \mathrm{pH}$. Toxic forms to aquatic organisms may occur at a lower or higher $\mathrm{pH}$.

P inactivation longevity does not typically 
exceed 15 years with an average of 13 years, that depends on phosphorus release rates and the applied dose. Alum longevity is typically 4-21 years in stratified lakes and 1-11 years in shallow lakes (Welch and Cooke 1999). According to Tandyrak et al. (2001) the positive effect of Lake Starodworskie (in Olsztyn, Poland) restoration persisted for 3 years. The well - known pattern of Lake Długie in Olsztyn shows, that using booster doses of chemicals can keep the lake in good condition for many years (Grochowska et al. 2017, Grochowska and Brzozowska 2015).

\section{Sediment Oxidation}

Riplox method that developed by Ripl to reduce lake's P-internal loading where the iron-redox reactions control $P$ release from sediments by enhancing the denitrification process and complexifying it with iron, that's done by direct-injection of nitrate, as; $\mathrm{Ca}\left(\mathrm{NO}_{3}\right)_{2}$, iron (as $\left.\mathrm{FeCl}_{3}\right)$, and lime $\left(\mathrm{CaCO}_{3}\right)$, which acts as an alternative electron acceptor to oxygen (Ripl 1986).

The liquid status of nitrate make it penetrates into the sediments easily, a harrow disc with tubes at its end dragged along lake's bottom with rate of 4-5 $\mathrm{m} / \mathrm{min}$, the restoration technique able to oxidize $15-20 \mathrm{~cm}$ of the sediments depth associated with a prevention of sulphate reduction therefore decreasing the formation of iron sulphide and leaving iron available to complex P (Lewtas et al. 2015, Cooke et al. 2005, Dokulil et al. 2000).

Regardless of the high cost, the added chemicals are naturally found and in high concentrations in unpolluted sediments making it less toxic to the aquatic life, but according to Łopata et al. (2020) intensive dosage range of chemicals can be invasive to the benthos. What is more, the mechanical movement of the sediments contributes to their resuspension and secondary pollution of the water column. Sediment oxidation process is expected to be succeed only if the P-internal loading is controlled by iron-redox reactions, the same of controlling $\mathrm{pH}$ and temperature. Furthermore, it is typically used only in shallow lakes with relatively flat bottoms due to the need of direct-injection of chemicals into sediments (Hickey and Gibbs 2009, Pettersson and Böstrom 1981).

\section{Algicide and Herbicides}

A wide range of chemicals have been used to control of nuisance algal blooms and dense growth of macrophytes, including copper sulphate $\left(\mathrm{CuSO}_{4}\right)$, silver nitrate $\left(\mathrm{AgNO}_{3}\right)$, potassium permanganate $\left(\mathrm{KMnO}_{4}\right)$, sodium hypochlorite $(\mathrm{NaOCl})$ and several different organic herbicides (Lam et al. 1995, Horne and Goldman 1974). Some of the other algicides were used, though on a very small scale, are rosin, amines, triazine $\left(\mathrm{C}_{3} \mathrm{H}_{3} \mathrm{~N}_{3}\right)$ derivatives, mixture of copper sulphate and silver nitrate, quaternary ammonium compounds, organic acids, aldehydes, and ketones (Singh 1982). Algicides impact vary with species, includes direct kill, photosynthesis inhibition, phosphorus absorption and nitrogen fixation (Havens 1994). At present, algicides are rarely used due to concerns about toxicity to non-target aquatic biota and, in some cases, human health, but algicides approach is still a popular method used by fishermen (Lewtas et al. 2015).

Copper salts particularly copper sulphate $\left(\mathrm{CuSO}_{4}\right)$ where widely used as an algicides in the past with data return back to 1921 (Lewtas et al. 2015). Cyanobacteria is highly sensitive to low concentrations of $\left(\mathrm{CuSO}_{4}\right)$, where $5-10 \mu \mathrm{g} \mathrm{Cu} / \mathrm{L}$ can suppress its activity (Janik et al. 1980).

In particular, algicides may accumulate in sediments and cause long-term contamination. its effects on eutrophication are temporary which require an annual treatment and its cost is relatively high. But what is critical, utilizing algicides create negative impacts on non-target organisms (Cooke et al. 2005). Targeted algae species could resist the applied algicides, where zooplankton and benthic invertebrates may be eliminated as a side effect (Lam et al. 1995). The decomposition of the sunken dead algae could deplete the dissolved oxygen in the lake creating anoxic conditions which increase ferrous iron, phosphorous, manganese, hydrogen sulphide and ammonia concentrations. According to Singh (1982), any fish-kills due to algicides implementing can generally be attributed to an improper application or due to an excess dose.

The immediate factor in the fight against algal bloom, especially in bays or bathing areas, is the exposure to barley straw. Its algistatics inhibit the proliferation of cyanobacterial cells

\section{Macrophytes removal}

Macrophytes plays an important role to balance lake's ecosystem and improve the water quality by absorbing nutrients and during the active 
growth periods, macrophytes and epiphyton may be a net sink for nutrients. Decomposition of the dead macrophytes after the vegetation period become an important source mobilizing nutrient from the sediments to the water column and depleting the dissolved oxygen. Adding to that, in some lakes macrophytes considered undesirable because its affect on the recreational uses (Dhote 2007, Landers 1982).

Internal nutrient loading from macrophyte decaying in many eutrophic lakes may be greater than external loading and it can participate approximately by half of the P-internal loading in lake. Thus, macrophyte harvesting may be the way to reduce the internal nutrient cycle (Cooke et al. 2005, Carpenter 1980). In eutrophic lakes, even where nutrient loading is controlled, it may still need several years of harvesting to have an impact on lake nutrient concentrations (Carpenter 1980, Burton et al. 1979).

As aquatic plants provide substrate, food, and a refuge for the aquatic fauna, reducing its impact fish, invertebrates and other species, moreover that may even promote algal blooms due to lack of competition (Burton et al. 1979, Lewtas et al. 2015).

\section{Floating treatment wetlands (FTW)}

It is an eco-technique for lake management and nutrients control, simulating the natural wetlands (Yeh et al. 2015). FTWs concept is supporting the hydroponically growth of the aquatic plants over water's surface by cultivate them on buoyant mats or rafts and its roots are immersed directly into the water below, an emergent plant (David 2013, Tanner et al. 2011).

The intertwined roots provide a large surface area for nutrient absorption, entrapment of fine suspended particulates and enhance biofilms growth, that catalyzing the microbial nutrient removal processes, such as denitrification, by creating anoxic local zone under the mat (Shahid et al. 2018). By shading the surface and buffering water turbulence, FTWs can also promote settling of suspended algae and solids beneath the mats (Headley and Tanner 2006, 2011).

The emergent plants have a higher need for nitrogen, which may decrease N:P and potentially promote the growth of cyanobacteria (Shapiro 1973). Bacteria and algae are important in P-cycle in water column, and the microbial uptake of phosphorus is rapid (Vymazal 2007). Consequently, a large FTWs surface area will indirectly mean a higher microbial mass and biofilms that increase the P-uptake. Harvesting the floating plants will increase the permanent nutrient removal from the lake (Headley and Tanner, 2006, 2011).

Floating wetland treatment is an easy implemented technology, adaptable to a numerous species of plant, and applicable in a variety of environments without requiring costly maintenance (Stewart et al. 2008). Anyhow, a potential precaution that large surface coverage of the lake create anoxic conditions and the FTWs require such a stable slowflow water.

\section{Biomanipulation}

Biomanipulation theory was originally based on the concept of cascading trophic interactions in aquatic food webs, an alteration of lake top-down food web, increasing piscivore abundance or reduce the planktivorous-fish will enhance the zooplankton e.g. Daphnia, grazing pressure on phytoplankton e.g. Cyanobacteria, Diatom and Green algae, and as a result improving lake's water clarity (Reynolds 1994, Shapiro and Wright 1984). Phytoplankton abundance reflects lake nutrients content and consider as a principle trophic statue indicator, and its related to the internal load cycle and external input of nutrient to the lake (Findlay et al. 2005, Hansson et al. 1998).

Biomanipulation associated improvements are: decreasing of water turbidity, chlorophyll-a, total phosphorous concentration, algal biomass and cyanobacterial blooms. Biomanipulation also increased transparency, that led to expansion of the submerged macrophyte by providing favorable conditions for the establishment of rooted plants (Triest et al. 2016, Ha et al. 2013). Furthermore, biomanipulation is inexpensive relative to other remediation techniques, does not require complex infrastructure or using toxic chemicals, and introducing predatory fish may enhance recreational fishing, but long-term results are rare, and the most successful biomanipulations have occurred in shallow and oligotrophic-mesotrophic lakes and most successful examples provide only data from the first 1-3 years (Kasprzak et al. 2003)

Biomanipulations may fails for various reasons, as; insufficient fish removing, immigration 
of planktivorous from other systems and recolonization, increase in invertebrates-planktivorous, increase the amount of Phytoplankton that are unable-to-grazed e.g. larger toxic cyanobacteria, resuspension of sediments by wind, low piscivores by eliminating fish, inability of many common algae to lake eutrophic status, replacement of fish predation by invertebrates e.g. Chaoborus, long-term instability of the fish population due to overstocking of piscivores (Ofir et al. 2017)

\section{Conclusion}

Lake is complexly intertwined system; each is a unique existing ecosystem in its own right and have its special circumstances. Numerous lake restoration techniques are existing, but still the best one is to stop the pollution source. Good lake's management and monitoring program will not be led to restoration stage, small practices can create huge effect.

Lake restoration procedure has to pass through consecutive steps, principally begin with a careful planning and well-study of each case, an implementation of the numerical models will enrich the knowledge of the lake ecosystem parameters and assist to predict the results.

Regardless the cost, combination of concurrent techniques seems to be effective approach same the same as enhance and support the natural self-purification process of the lake.

Access to updated database system, cooperation between limnologist and scientific institution, link a lake with modern technologies and sciences and endeavor to find new eco-innovative methods are topics that should be worked on constantly. Water is life.

\section{Acknowledgements}

Mohammed Z. Alhamarna is a recipient of a scholarship from the Programme Interdisciplinary Doctoral Studies in Bioeconomy (POWR.03.02.0000-I034/16-00), which is funded by the European Social Funds.

\section{References}

[USEPA] Omernik J.M., 1977, Non-point source - stream nutrient level relationships: a nationwide study, EPA
Ecological Research Series. U.S. Environmental Protection Agency.

[USEPA] Pastorok R.A., Ginn T.C., Lorenzen M.W., 1981, Evaluation of aeration/circulation as a lake restoration technique, Environmental Research Laboratory, Office of Research and Development, US Environmental Protection Agency.

[USEPA] Theis T.L.,1979. Treatment of Lake Charles East, Indiana sands with fly ash. US Environmental Protection Agency.

[USEPA] Welch E.B., 1981, The dilution/flushing technique in lake restoration, US Environmental Protection Agency.

[USEPA], 2000, Guiding principles for constructed treatment wetlands: Providing for water quality and wildlife habitat, United States Environmental Protection Agency.

Alberts E.E, Neibling W.H., Moldenhauer W.C., 1981, Transport of sediment nitrogen and phosphorus in runoff through cornstalk residue strips, Soil Science Society of America Journal 45:1177-1184.

Arsénio P., Rodríguez-González P., Bernez I., Dias F., Bugalho M., Dufour S., 2019, Riparian vegetation restoration: Does social perception reflect ecological value?: Social perception of riparian vegetation restoration, River Research and Applications. Source: nlinelibrary.wiley.com/doi/epdf/10.1002/rra.3514.

Ashley K., 2011, Hypolimnetic Aeration of A Naturally Eutrophic Lake: Physical and Chemical Effects, Canadian Journal of Fisheries and Aquatic Sciences, 40: 1343-1359.

Ashley K., Nordin R., 1999, Lake aeration in British Columbia: Applications and experiences, [In:] Murphy T. and Munawar M. (Eds), Aquatic Restoration in Canada, Backhuys, Leiden The Netherlands: 87-108.

Ashley K.I., 1987, Artificial circulation in British Columbia: Review and evaluation (Fisheries Technical Circular No. 78), British Columbia Ministry of Environment and Parks.

Ashley K.I., Mavinic DS, Hall KJ., 1992, Bench-scale study of oxygen transfer in coarse bubble diffused aeration, Water Research, 26: 1289-1295.

Augustyniak R., 2018, Wpływ czynników fizyczno chemicznych i mikrobiologicznych na zasilanie wewnętrzne fosforem wód wybranych jezior miejskich [monograph], PAN, Lublin, pp. 242.

Bartoszek L., Koszelnik P., 2015, Lakes and reservoirs restoration - Short description of the chosen methods, [In:] Tomaszek J., Koszelnik P. (Eds.), Progress in Environmental Engineering, Taylor \& Francis Group, London: 51-58.

Björk S., Pokorný J., Hauser V., 2010, Restoration of lakes through sediment removal, with case studies from lake Trummen, Sveden and Vajgar, Czech Republic. [In:] Restoration of lakes, Streams, Foodplains and Bogs in Europe. Principlas and Case Studies, [Ed.] Eiselltová M, Springer, Berlin/Heiderberg, Germany 
Bormann H., Giertz S., Diekkrüger B., 2005, Hydrological catchment models: Process representation, data availability and applicability for water management - Case study for Benin, IAHS-AISH Publ. 295: 86-93.

Born S.M., 1979, Lake rehabilitation: a status report, Environ. Manage. 3(2): 145-153.

Braskerud B.C., 2002, Factors affecting phosphorus retention in small constructed wetlands treating agricultural non-point source pollution, Ecological Engineering 19(1): 41-62.

Burton T.M., King D.L., Ervin J.L., 1979, Aquatic plant harvesting as a lake restoration technique. In: Lake Restoration, Proceedings of a National Conference, USEPA 440/5-79-001: 177-186.

Cairns. J. Jr, 1992, Restoration of Aquatic Ecosystems. Science, Technology and Public Policy. National Academy Press, Washington, DC.

Carpenter S.R., 1980, Enrichment of Lake Wingra, Wisconsin, by submersed macrophyte decay, Ecology. 61: 1145-1155.

Carvahlo L., Beklioglu M., Moss B., 1995, Changes in a deep lake following sewage diversion - a challenge to the orthodoxy of external phosphorus content as a restoration strategy? Freshwater Biol. 34: 399 - 410.

Clerici, N., Weissteiner C., Paracchini M.L., Strobl P., 2016,. Riparian zones where green and blue networks meet: pan-European zonation modelling based on remote sensing and GIS. Luxembourg: Publications Office of the European Union, 2011. (European Union. JRC Scientific and Technical Reports, 24774). DOI: 10.2788/80271. Source: https://ec.europa. eu/jrc/ en/publication/eur-scientific-and-technical-research-reports/ riparian-zones-where-green-and-blue-networks-meet-pan-europeanzonation-modelling-based.

Cooke G.D., 1980, Covering bottom sediments as a lake restoration technique, American Water Resources Association, Water Resources Bulletin 16(5): 921-926

Cooke G.D., Carlson R.E., 1989, Reservoir Management for Water Quality and THM Precursor Control, AWWA Research Foundation, Denver, CO.

Cooke G.D., Welch E.B, Peterson SA, Newroth PR., 1993, Restoration and, Management of Lakes \& and Reservoirs, Boca Raton, Florida, pp. 616.

Cullen P., Forsberg C., 1988, Experiences with reducing point sources of phosphorus to lakes, Hydrobiologia 170: 321-336.

Dąbrowska J., 2008, Methods of reclamation of water reservoirs, Acta Sci Pol Formatio Circumiectus 7(1): 63-79.

Dąbrowska J., Bawiec A., Pawęska K., Kamińska J., Stodolak R., 2017, Assessing the Impact of Wastewater Effluent Diversion on Water Quality, Pol. J. Environ. Stud. 26 (1): 9-16 Source: https://doi.org/10.15244/ pjoes/64748.

David J., 2013, What Is a Floating Treatment Wetland? Floating Treatment Wetlands, Biol. Syst. Eng. 1-5
Dhote S., 2007, Role of macrophytes in improving water quality of an aquatic eco-system, Journal of Applied Sciences and Environmental Management 11(4): 133-135.

Dobson H.F.H., Gilbertson M., Sly P.G., 1974, A summary and comparison of nutrients and related water quality in lakes Erie, Ontario, Huron and Superior, Journal of the Fisheries Research Board Canada 31: 731-738.

Dokulil M.T., Teubner K., Donabaum K., 2000, Restoration of a shallow, ground-water fed urban lake using a combination of internal management strategies: a case study. Advances in Limnology, 55: 271-282.

Dufour S., Rodríguez-González P., 2019, Riparian zone Riparian vegetation definition: principles and recommendations, Report, COST Action CA16208 CONVERGES, pp. 20 Source: https://converges.eu/resources/riparian-zone-riparian-vegetation-definition-principles-and-recommendations/)

Dunst R.C., Born S.M., Uttomark S.A., Smith S.A., Nichols S.A., Peterson J.O., Knauer D.R., Serns S.L., Winter D.R., Wirth TL., 1974, Survey of lake rehabilitation techniques and experience, Technical Bulletin No. 75, Wisconsin Department of Natural Resources, pp. 179.

Fast A.W., Lorenzen M.W., 1976, Synoptic survey of hypolimnetic aeration, J. Envir. Engin. Div. 102.6: 1161 1173.

Findlay D D.L., Vanni M M.J., Paterson M.J., Mills K.H., Kasian S.E.M., Findlay W.J., Salki A.G., 2005, Dynamics of a boreal lake ecosystem during a long-term manipulation of top predators, Ecosystems 8: 603618.

Gawrońska H., Łopata M., Jaworska B., 2007. The effectivenrs of the phosphorus inactivation method in reducing the trophy of lakes od different morphometrical and hydrological features. Limnological Review 7(1): 27-34.

Gibbs M., Özkundakci D., 2011, Effects of a modified zeolite on $\mathrm{P}$ and $\mathrm{N}$ processes and fluxes across the lake sediment-water interface using core incubations. Hydrobiologia 661(1): 21-35.

Gibbs M.M., Hickey C.W., Özkundakci D., 2011, Sustainability assessment and comparison of efficacy of four P-inactivation agents for managing internal phosphorus loads in lakes: sediment incubations. Hydrobiologia 658(1): 253-275.

Glibert P.M., Seitzinger S., Heil C.A., Burkholder J.M., Parrow M.W., Codispoti L.A., Kelly V., 2005, The role of eutrophication in the global proliferation of harmful algal blooms, Oceanography 18: 198-209.

Grochowska J., Augustyniak R., Łopata M., 2017, How durable is the improvement of environmental conditions in a lake after the termination of restoration treatments. Ecological Engineering 104: 23-29.

Grochowska J., Augustyniak R., Łopata, M., Tandyrak R., 2020, Is It Possible to Restore a Heavily Polluted, Shallow, Urban Lake? Applied Sciences 10(11), 3698. 
Grochowska J., Brzozowska R., Łopata M., 2013, Durability of changes in phosphorus compounds in water of an urban lake after application of two reclamation methods. Water Science and Technology 68(1): 234239

Grochowska, J., Brzozowska R., 2015, Influence of different recultivation methods on durability of nitrogen compounds changes in the waters of an urban lake. Water and Environment Journal 29(2): 228-235.

Gu B.W., Lee C.G., Lee T. G., Park S.J., 2017, Evaluation of sediment capping with activated carbon and nonwoven fabric mat to interrupt nutrient release from lake sediments. Science of the Total Environment 599: 413-421.

Ha J., Saneyoshi M., Park H, Toda H., Kitano S., Homma T., Shiina T., Moryiama Y., Hang K., Hanazato T., 2013, Lake restoration by biomanipulation using piscivore and Daphnia stocking; results of the biomanipulation in Japan, Limnology14: 19-30 Source: https://doi.org/10.1007/s10201-012-0381-9

Halsey T.G., 1968, Autumnal and overwinter limnology of three small eutrophic lakes with particular reference to experimental circulation and trout mortality, Journal of the Fisheries Research Board of Canada 25: 81-99.

Hamm A., 1978, Nutrient load and nutrient balance of some subalpine lakes after sewage diversion, Proceedings of 20th Congress Internationale Vereiningung fur Theoretische und Angenwandte Limnologie, Copenhagen, p. 975-984.

Hansson L.A., Annadotter H., Bergman E., Hamrin S.F., Jeppesen E., Kairosalo T., Luokkanen E., Nilsson P.A., Sřndergaard M., Strand J., 1998, Biomanipulation as an application of food chain theory: Constraints, synthesis and recommendations for temperate lakes, Ecosystems 1: 558-574.

Headley T.R, Tanner C.C., 2006, Application of floating wetlands for enhanced stormwater treatment: a review, Auckland Regional Council Technical publication TP324, p. 93. Source: http://www.arc.govt. $\mathrm{nz} /$ plans/technical-publications/technical-publications-301- 350.cfm.

Headley T.R., Tanner C.C., 2011, Innovations in constructed wetland treatment of stormwaters utilising floating emergent macrophytes. Critical Reviews in Environmental Science and Technology.

Hickey C.W., Gibbs M.M., 2009, Lake sediment phosphorus release management, Decision support and risk assessment framework, New Zealand Journal of Marine and Freshwater Research 43: 819-856.

Hooper F.F., Ball R.C., Tanner H.A., 1953, An experiment in the artificial circulation of a small Michigan lake, Transactions of the American Fisheries Society 82: 22-241.

Horne A.J., Goldman C.R., 1974, Suppression of nitrogen fixation by blue-green algae in a eutrophic lake with trace additions of copper, Science 83: 409-411.
Hosomi M., Sudo R., 1992, Development of the phosphorus dynamic model in sediment - water system and assessment of eutrophication control programs, Water Sci. Technol. 26: 7 - 8

Hupfer M., Gachter R., Giovanoli R., 1995, Transformation of phosphorus species in settling seston and during early sediment diagenesis, Aquatic Sciences 57(4) : 305-324.

Huser B.J., Pilgrim K.M., 2014, A simple model for predicting aluminum bound phosphorus formation and internal loading reduction in lakes after aluminum addition to lake sediment, Water Research 53: 378-85. Source: http://dx.doi.org/10.1016/j.watres.2014.01.062

Janik J.J., Taylor W.D., Barks J.W., 1980, A compilation of common algal control and management techniques, U.S. Army Corps of Engineers, Washington, pp. 53

Jeppesen E., Sřndergaard M., Jensen J.P., Havens K.E., Anneville O., Carvalho L., Coveney M.F., Deneke R., Dokulil M.T., Foy B., 2005, Lake responses to reduced nutrient loading - an analysis of contemporary long-term data from 35 case studies, Freshw. Biol. 50: $1747-1771$.

Kajak Z., 2002, Hydrobiology - Limnology. In Inland Water Ecosystems, PWN, Warsaw, Poland, pp. 212.

Kasprzak P., Koschel R., Krienitz L., Gonsiorczyk T., Anwand K., Laude U., Wysujack K., Brach H., Mehner T., 2003, Reduction of nutrient loading, planktivore removal and piscivore stocking as tools in water quality management: The feldberger haussee biomanipulation project, Limnologica, 33:190-204. Source: https://doi.org/https://doi.org/10.1016/S00759511(03)80013-0

Katsev S., Tsandev I., L'Heureux I., Rancourt D.G., 2006, Factors controlling long-term phosphorus efflux from lake sediments: Exploratory reactive-transport modeling, Chemical Geology 234: 127-147.

Keating K.I., 1977, Blue-green algal inhibition of diatom growth: transition from mesotrophic to eutrophic community structure, Science 199: 971-973.

Kim G., Jeong W., Choi S., Khim J., 2007, Sand capping for controlling phosphorus release from lake sediments, Environmental Technology 28(4): 381-389.

Klapper H., 2003, Technologies for Lake Restoration, Journal of Limnology, 62(1): 73-90. Source: https:// doi.org/10.4081/jlimnol.2003.s1.73

Lam A.K.Y., Prepas E.E, Spink D, Hrudey S.E., 1995, Chemical control of hepatotoxic phytoplankton blooms: Implications for human health, Water Research 29: 1845-1854.

Landers D.H., 1982, Effects of naturally senescing macrophytes on nutrient chemistry and chlorophyll a of surrounding water, Limnology and Oceanography 27: 428-439.

Lewtas K., Paterson M., Venema H.D., Roy D., 2015, Manitoba Prairie Lakes: Eutrophication and In-Lake Remediation Treatments, International Institute for 
Sustainable Development (IISD), Manitoba, Canada. Source: www.jstor.org/stable/resrep 14759.

Łopata M., Augustyniak (Brzozowska) R., Grochowska J., Parszuto K., Tandyrak R., 2020, Selected Aspects of Lake Restorations in Poland, [In:] Korzeniewska E., Harnisz M. (Eds.), Polish River Basins and Lakes - Part II, Springer-Nature, Switzerland: 327-352.

Łopata M., Wiśniewski G., 2013, The use of surface water flow to improve oxygen condition in hypertrophic lake, Global Journal of Advances in Pure \& Applied Sciences 1: 687 - 692 .

Lossow K., 1995, Możliwości i uwarunkowania rekultywacji jezior w Polsce. XVI Sympozjum „Problemy ochrony, zagospodarowania i rekultywacji antropogenicznych zbiorników wodnych”. Zabrze, 115-121.

Lossow K., Gawrońska H., 2000, Jeziora, rekultywacja, przegląd metod, Przegląd Komunalny 9(108): 91 106.

Lossow K., Gawrońska H., Tandyrak R., 1998. Badanie możliwości zastosowania popiołów lotnych do rekultywacji jezior, Bad. Limnol. 1:215 - 224.

McQueen D.J., Lean D.R.S., 1984, Aeration of anoxic hypolimnetic water: Effects of nitrogen and P concentrations, Verhandlungen des Internationalen Verein Limnologie 22: 267-276.

McQueen D.J., Story V.A., 1986, Impact of hypolimnetic aeration on zooplankton and phytoplankton populations, Environmental Technology Letters 7: 31-44.

Mehner T., Benndorf J., Kasprzak P., Koschel R., 2002, Biomanipulation of lake ecosystems: Successful applications and expanding complexity in the underlying science, Freshwater Biology 47(12): 2453-2465.

Mercier P., Perret J., 1949, Aeration station of Lake Bret, Monatsbull, Schweiz. Ver. Gas, u Wasserfach. Monatsbull. 29: 25-30.

Mientki Cz., 1986, Wpływ usuwania wód hypolimnionu na układy termiczne i tlenowe oraz zawartość azotu i fosforu w wodzie Jeziora Kortowskiego, Acta. Acad. Agricult. Techn. Olst., Protectio Aquarium et Piscatoria, Supl. A, 14: 3 - 53.

Molot L.A., Watson S.B., Creed I.F., Trick CG, McCabe SK, Verschoor MJ, Sorichetti RJ, Powe C, Venkiteswaran JJ, Schiff SL., 2014, A novel model for cyanobacteria bloom formation: the critical role of anoxia and ferrous iron, Freshwater Biology 59: 1323-1340.

Nürnberg G.K., 1988, Prediction of phosphorus release rates from total and reductant soluble phosphorus in anoxic lake sediments, Canadian Journal of Fisheries and Aquatic Sciences 45: 574-580.

Nürnberg G.K., 2019, Hypolimnetic withdrawal as a lake restoration technique: determination of feasibility and continued benefits, Hydrobiologia 1 - 15. Source: https://doi.org/10.1007/s10750-019-04094-z

Ofir E., Heymans J.J., Shapiro J., Goren M., Spanier E., Gal, G. 2017, Predicting the impact of Lake Biomanipulation based on food-web modelingmodelling - Lake Kinneret as a case study, Ecol. Modell. 348:14-24.
Source: $\quad$ https://doi.org/https://doi.org/10.1016/j. ecolmodel.2016.12.019

Palermo M., Schroeder P., Estes T., Francingues N., 2008, Technical Guidelines for Environmental Dredging of Contaminated Sediments, pp. 302.

Parszuto K., Tandyrak R., Grochowska J., Sieńska J., 2018. Restoration of the three lakes in Olsztyn, in the context of the development of recreational area city. Prace i Studia Geograficzne 63(4): 129-144.

Pastorok R.A., Lorenzen M.W., Ginn T.C., 1982, Environmental Aspects of Artificial Aeration and Oxygenation of Reservoirs: A Review of Theory, Techniques, and Experiences (Technical Report). U.S. Army Corps of Engineers.

Payraudeau S., Tournoud M.G., Cernesson F., Picot B., 2001, Annual nutrients export modelling by analysis of land use and topographic information: case of a small Mediterranean catchment, Water Sci. Technol. 44(2-3): 321-327.

Pettersson K. Boström B., 1981, En kritisk granskning av foreslagna metoder for nitratbehandling av sediment, Vatten 38: 74.

Reynolds C.S., 1994, The ecological basis for the successful biomanipulation of aquatic communities, Archiv für Hydrobiologia 130: 1-33.

Riis T., Kelly-Quinn M., Aguiar F.C., Manolaki P., Bruno D., Bejarano M.D., Clerici N, Fernandes M.R., Franco J.C., Pettit N., Portela A.P., Tammeorg O., Tammeorg P., Rodríguez-González P.M., Dufour S., 2020, Global Overview of Ecosystem Services Provided by Riparian Vegetation, Bioscience 70: 501-514. Source: https://doi.org/10.1093/biosci/biaa041.

Ripl W., 1986, Biochemical oxidation of polluted lake sediment with nitrate - A new restoration method, Ambio 5(3): 132-135.

Sas H., 1990, Lake restoration by reduction of nutrient loading: expectations, experiences, extrapolations, Internationale Vereinigung für theoretische und angewandte Limnologie: Verhandlungen 24(1): 247251.

Schmitt T.J., Dosskey M.G., Hoagland K.D., 1999, Filter strip performance and processes for different vegetation, widths, and contaminants, Journal of Environmental Quality 28: 1479-1489.

Schönach P., Tapio P., Holmroos H., Horppila J., Niemistö J., Nygrén N.A., Tammeorg O., Massa I., 2017, Persistency of artificial aeration at hypertrophic Lake Tuusulanjärvi: A sociohistorical analysis, Ambio 46 (8): 865-877.

Shapiro J., 1973, Blue-green algae: Why they become abundant? Science 197: 382-384.

Shapiro J., Wright D.I., 1984, Lake restoration by biomanipulations. Round Lake, Minnesota-the first two years, Freshwater Biol. 14: 37 l-383.

Shepherd B., Harper D., Millington A., 1999, Modelling catchment-scale nutrient transport to watercourses in the U.K., Hydrobiologia 395: 227-238. 
Source: https://doi.org/10.1023/A:1017009921688

Singh K.P., 1982, Lake restoration methods and feasibility of water quality management in Lake of the Woods. Illinois State Water Survey, Contract Report 301.

Singleton V. L., Little J.C., 2006, Designing hypolimnetic aeration and oxygenation systems - A review, Environmental Science and Technology 40: 7512-7520.

Siwek H., Włodarczyk M., Czerniawski R., 2018, Trophic state and oxygen conditions of waters aerated with pulverising aerator: the results from seven lakes in Poland, Water 10(2), 219.

Smolders A.J.P., Lamers L.P.M., Lucassen E.C.H.E., Van der Velde G.J.G.M., Roelofs J.G.M., 2006, Internal eutrophication: How it works and what to do about it: a review, Chemistry and Ecology 22: 93-111.

Sřndergaard M., Jeppesen E., Lauridsen T., Skov C., Van Nes E. H., Roijackers R., Lammens E., Portielje R., 2007, lake restoration: successes, failures and long-term effects. J. Appl. Ecol. 44:1095-1105 .

Sřnnichsen T., 1978, Toxicity of phosphate-reducing agent (aluminum sulphate) on the zooplankton in the Lake Lyngby Sř, Verh. Internat.Verein. Limnol. 709 713.

Stewart F.M., Mulholland T., Cunningham A.B., Kania B.G., Osterlund M.T., 2008, Floating islands as an alternation to constructed wetlands for treatment of excess nutrients from agricultural and municipal waste Results of laboratory-scale tests, Land Contamination \& Reclamation 16(1): 25-33.

Tandyrak R., Gołaś I., Parszuto K., Bowszys M., Szymański D., Harnisz M., Brudniak A., Wysocka I., 2016, The effect of lake restoration by the hypolimnetic withdrawal method on the intensity of ambient odour, Journal of Limnology 75(36). DOI: 10.4081/jlimnol.2016.1400.

Tandyrak R., Lossow K., Gawrońska H., 2001, Long term changes of environmental conditions in a lake restored by phosphorus inactivation, Limnol. Rev.,1: $263-270$.

Tanner C.C., Sukias J.P.S., Park J., Yates C., Headley T., 2011, Floating treatment wetlands: a new tool for nu- trient management in lakes and waterways, Source: https://www.academia.edu/22615434/Floating_Treatment_Wetlands_A_New_Tool_for_Nutrient_Management_in_Lakes_and_Waterways

Thomas E.A., 1944. Ueber Maßnahmen gegen die Eutrophierung unserer Seen und zur Förderungihrer biologischen Produktionskraft. Schweiz. Fish. Zeit. 7(8):1 $-8$.

Todini E., 2007, Hydrological Catchment Modelling: Past, Present and Future, Hydrology and Earth System Sciences. Source: 11. 10.5194/hess-11-468-2007.

Triest L., Stiers I., Van Onsem S., 2016, Biomanipulation as a nature-based solution to reduce cyanobacterial blooms, Aquat Ecol' 50: 461-483. Source: https:// doi.org/10.1007/s10452-015-9548-x

Vymazal J., 2007, Removal of nutrients in various types of constructed wetlands, The Science of the Total Environment 380: 48-65.

Wall D.H., Palmer M.A., Snelgrove P.V.R., 2001, Biodiversity in critical transition zones between terrestrial, fresh water, and marine soils and sediments: Processes, linkages and management implications, Ecosystems 4: 418-420.

Welch E.B., Cooke G.D., 1999, Effectiveness and longevity of phosphorus inactivation with alum. Lake and Reservoir Management 15 (1): 5-27.

Wiśniewski G., 2007, Permanence of the effects of the Lake Kortowskie restoration, started in 1956 [Summary], [In:] Anthropogenic and natural transformation of lakes, 1:126 - 129 .

Yeh N., Yeh P., Chang Y.H., 2015, Artificial floating islands for environmental improvement, Renewable and Sustainable Energy Reviews, 47: 616-622.

Young W.J., Marston F.M., Davis R.J., 1996, Nutrient Exports and Land Use in Australian Catchments, J. of Env. Manag. 47 (2): 165-183.

Zhu Y., Tang W., Jin X., Shan B., 2019, Using biochar capping to reduce nitrogen release from sediments in eutrophic lakes. Science of the Total Environment 646: 93-104. 